\title{
Treaty of Rawalpindi of 1919 Hundred Years On
}

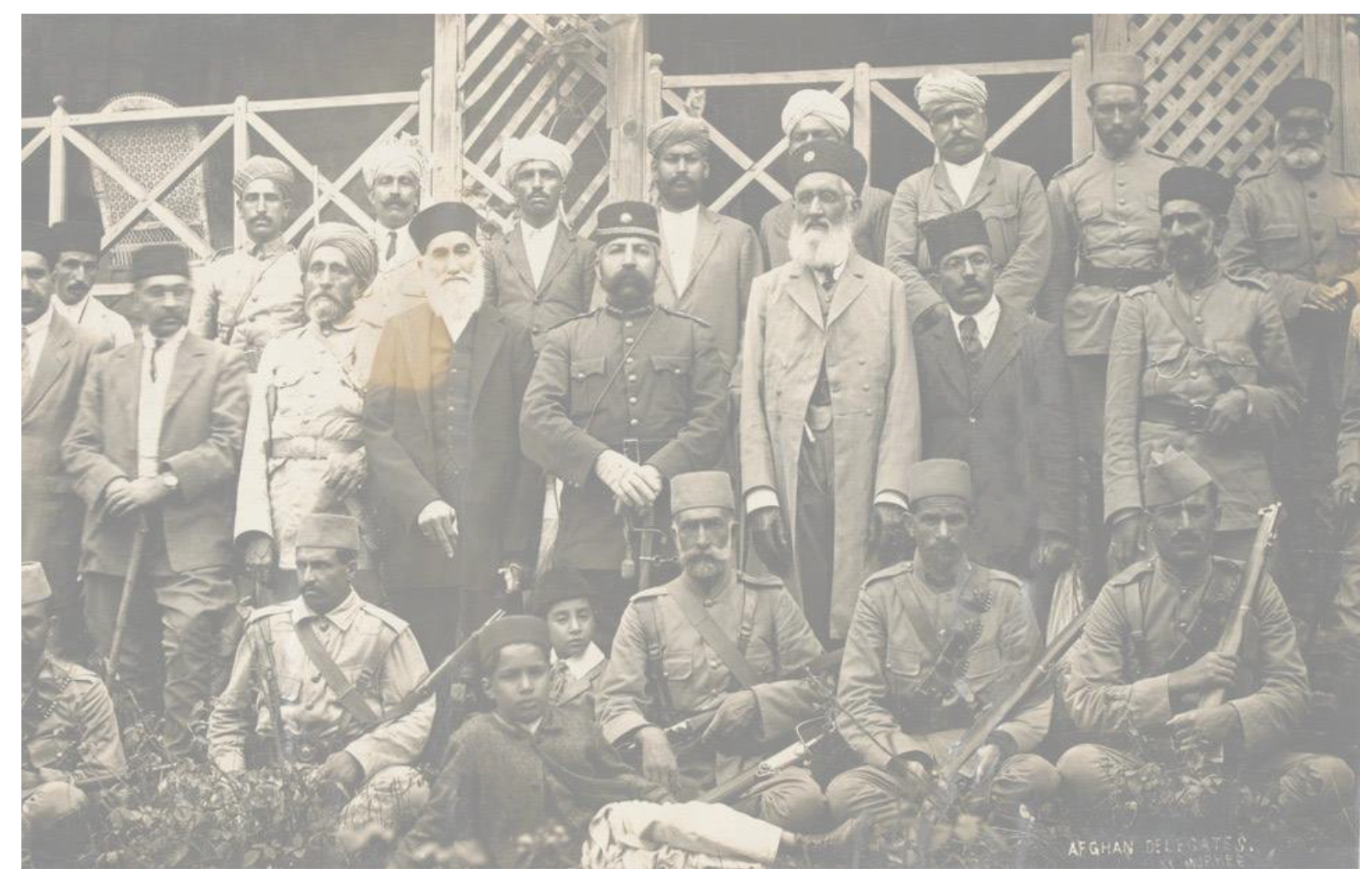

Syed Atif Raza 


\section{$\underline{\text { Abstract }}$}

The Treaty of Rawalpindi concluded in August 1919 between the British India and Afghanistan, in the aftermath of the brief Anglo-Afghan war earlier that year, was a watershed moment in the British India's "frontier question" and emergence of an independent Afghanistan. The Treaty holds immense legal and political value in the development of Afghanistan and its relations with Pakistan after 1947. However, only a scant attention has been devoted to this landmark Treaty by the academics and practitioners alike. In addition to explicitly recognizing Afghanistan's independence, the Treaty, once and for all, settled the question of British India's western boundary with Afghanistan, which was earlier established in 1893 in Durand Line Agreement. This working paper fills the gap in existing literature by shedding light on the circumstances that led to the Treaty of Rawalpindi and its legal and political significance for Afghanistan and Pakistan and their bilateral relations. 
On 19 August 2019, Afghan people and government celebrated hundred years of their "independence". This was in reference to a short war between Afghanistan and British India followed by the Treaty of Rawalpindi (also known as Anglo-Afghan Treaty of 1919), signed on 8 August 1919.

The Treaty of Rawalpindi was the culmination of century-old fighting, intrigues, wars and treaties between British India and Afghanistan. The Treaty formally brought an end to the Third Anglo-Afghan War - a brief war that started on 4 May 1919 when Afghanistan invaded British India. A ceasefire was announced on 3 June 1919 and negotiations started forthwith with meeting of Afghan and British delegations at the Rawalpindi Peace Conference.

Scant consideration has been given to this Treaty in the literature, which was in fact, a significant moment in the history of Afghanistan and its relations with British India and subsequently its successor state Pakistan (in so far as relations with Afghanistan are concerned). Legal aspects of the Treaty have been afforded even less attention. Therefore, the need was felt to analyze the Treaty in its historical context with legal and political implications for Pakistan, Afghanistan and the region beyond.

\section{Setting the Scene}

Afghanistan, as a modern political entity, is primarily a British construct. Sandwiched between the Russian Empire and the British Indian Empire, it served as a useful buffer for both not to engage directly during the era of the Great Game (sort of nineteenth century Cold War!). Expanding British influence in the Indian subcontinent in the early part of the nineteenth century inevitably brought them to a collision course with frontier tribes and Afghans. Mutual relations remained hostile due to severe interference by the British in Afghan succession disputes and confrontations at the frontier regions, resulting in the First Anglo-Afghan War from 1839-1842 and the Second Anglo-Afghan War from 1878-1880.

Despite British intervention to install Yaqub Khan during the Second Afghan War, Abdul Rahman became Amir of Afghanistan in 1880. Abdul Rahman leading "a government of miscellaneous assortment of tribes and peoples" relied on two-pronged strategies - maintain balance between the Britain and Russia and whilst remaining self-isolated, consolidate the territorial and social integrity of Afghanistan. Abdul Rahman is thus credited for uniting Afghans and ending infighting. He also negotiated Durand Line Agreement with the British in 1893 that marked international border between Afghanistan and the British India.

His successor, Habibullah Khan confirmed previous arrangements, including border agreement through the Anglo-Afghan Treaty of 1905. He maintained a

\footnotetext{
${ }^{1}$ Col. Sir T. Hungerford Holdich, The Indian Borderland - 1880-1900 (London, 1901) - pp. 226
} 
policy of neutrality during the Second World War, even in the face of massive public support to Ottoman Turkey, that eventually led to his assassination by persons affiliated with anti-British movement in February 1919.

Amanullah Khan who ascended the throne in February 1919 was wary of British restrictions on his country including on Afghanistan's foreign relations. Immediately on assuming the throne, Amanullah Khan adopted anti-British stance and insisted on securing "independence" from British influence. To this end, he wrote letters to the British Viceroy in India in March and again in May 1919, urging the immediate start of negotiations for a treaty of friendship. Simultaneously Amanullah Khan ordered his troops to stay ready for the war ${ }^{2}$. However, British authorities were not prepared to change the status-quo. With continued British indifference and to deflect domestic attention from succession disputes, Amanullah Khan resorted to armed attacks on British India that started the Third Anglo-Afghan War.

Amanullah Khan's royal decree (firman) urging tribesmen to take up arms against British authorities also seemed to have exploited disturbance and great unrest in British India those days. Less than a month ago, British soldiers under the command of Acting Brigadier General Reginald Dyer opened fires on unarmed civilians protesting against infamous law Rowlatt Bill, in Jallianwala Bagh, Amritsar, killing at least 400 men and women.

As has been repeated over and over in Afghanistan's history, Amanullah Khan's call to arms was loaded with references to "expression of Islamic sympathy and human feeling towards mankind". On the other hand, in his private communication with Viceroy, Amanullah Khan asked for "abolishing the tyrannical laws and recognizing the absolute independence, equal rights and freedom in all respects of the Government of Afghanistan3".

This was also when Paris Peace Conference of 1919-1920 was in full swing. British government was therefore more sensitive not to let the situation go beyond a certain point where it could affect negotiations at the Paris Peace Conference. Also, on Afghanistan's northern frontier, newly established Bolsheviks were making headway. British had to deal with an Afghan nation "impregnated with the world spirit of self-determination and national freedom...impatient of any restraint on its absolute independence 4 "

Surprised as they were, the British retaliated with an aerial campaign against Afghanistan in which Amanullah Khan's house was also attacked. This was first

\footnotetext{
${ }^{2}$ Maximilian Drephal, Afghanistan and the Coloniality of Diplomacy - The British Legation in Kabul 1922-1948 (2019), Cambridge Imperial and Post-Colonial Studies Series - pp. 48-49

${ }^{3}$ Ludwig W. Adamec, Afghanistan, 1900-1923 - A Diplomatic History, University of California Berkeley and Los Angeles (1967) - pp. 114

${ }^{4}$ Government of India, Foreign and Political Department, no. 73, 2 October 1919, para. 5, IOR/L/PS/10/808, op. cit., BL.
} 
aerial attack in Afghanistan's history5. The fear of blitzkrieg over Afghan capital and cities convinced Amanullah Khan to swiftly resort to negotiations ${ }^{6}$. Nonetheless, despite aerial bombing campaign against Afghanistan, British had also realized the harsh reality of sliding control over Afghanistan, which was duly confirmed in swift agreement to come to the negotiating table?

Exchange of letters between Lord Chelmsford, British Viceroy and Amanullah Khan led to an understanding of ceasing fire and coming to a negotiated settlement. On the Viceroy's suggestion, the peace conference was convened in Rawalpindi.

\section{Rawalpindi Peace Conference}

Afghan delegation was led by Ali Ahmed Khan, Amanullah Khan's cousin and Afghanistan's Commissary for Home Affairs (Interior Minister). Later on, he was governor of Kabul under Amanullah Khan, eventually executed in July 1929 with the downfall of his patron King. Ali Ahmed Khan was supported by Abdul Ghani, an Indian Muslim who had previously served as Secretary to Abdul Rahman Khan for three years and Abdul Hadi Dawai, a poet, diplomat and government official who was later elected senator and became president of the senate from 1966 to $1973^{8}$. Also included in the delegation was Diwan Narinjan Das, the Hindu banker who had been Habibullah Khan's Chancellor of the Exchequer. British delegation was led by A. H. Grant, Foreign Secretary of the Government of India.

Some have observed that Amanullah Khan's delegation of plenipotentiary powers to his diplomatic mission was "an amazing departure from the old autocratic system" 9 . It is equally noteworthy that delegation chosen were mostly considered "pro-British" while those with hawkish views such as Minister for Commerce were conspicuous with their absence.

The Conference ${ }^{10}$ started on 26 July 1919 where the heads of both delegations delivered their initial statements. In the second meeting on 29 July, Afghan delegation cited reasons for Afghanistan's deteriorating relations with British, including the latter's refusal to allow Afghan representative to the Paris Peace Conference. During the third meeting on 31 July, British finally presented their demands which were rejected by Afghan delegation. However, with the fourth

\footnotetext{
${ }^{5}$ See Meredith Runion, The History of Afghanistan (2007) - pp. 89

${ }^{6}$ Edgar O'Ballance credits aerial bombing as a major factor in convincing Afghans to abandon their campaign against British and resort to negotiations, otherwise the ground troop situation was tilted in favor of Afghans. Edgar O'Ballance, Afghan Wars 1839-1992 - What Britain Gave Up and the Soviet Union Lost (1993) - pp. 7071

${ }^{7}$ See Christopher M. Wyatt, Diplomacy and Strategy during the Great Game (2011) - pp. 213

8 Detailed biographies can be found at Ludwig Adamec, Historical Dictionary of Afghanistan, (Third edition, The Scarecrow Press, Oxford, 2003)

${ }^{9}$ See Maximilian Drephal (2019) supra - pp. 54

10 Ludwig Adamec in his seminal work provides a detailed account of negotiations at the Rawalpindi Peace Conference.
} 
meeting on 4 August, Afghans relented and accepted the treaty in principle with some textual suggestions. Fifth meeting took place on 6 August where British submitted their text. Two days later, on 8 August 1919 the Treaty was signed.

British Indian authorities did not immediately get a final nod from London in finalizing the Treaty. It has been argued that Viceroy Lord Chelmsford and his delegate Sir H.A.R. Grant had brought their liberal viewpoints to the negotiating table of giving generous peace to Amanullah Khan ${ }^{11}$. Sir Grant and his Viceroy strongly conveyed to London that controlling foreign relations of another country without physical presence at any time of the controller or his agents could not continue for very long ${ }^{12}$.

\section{Decoding the Text}

While the complete text of the Treaty is given in the Annex of this paper, a brief analysis of the text is given below.

For the first time, references to "independent" and "Government of Afghanistan" were included in the title of any treaty with Afghanistan. During the negotiations, Afghan delegation asked for definite written assurances with regards to Afghanistan's independence of foreign relations. In making a case for granting this "favor" to Afghanistan, Lord Chelmsford urged London to let go "our hold on the shadow" as Afghanistan would still be a country economically and militarily reliant on Britain ${ }^{13}$. British Cabinet only reluctantly accepted indirect recognition of Afghanistan's independence and the agreement included the phrase 'Independent Afghan Government' in the title. Though, it may be noted that there was no mention of Afghanistan as an 'independent' or 'free' nation in the Treaty's substantive clauses.

In rather condescending or retributory tone, the Treaty (Article II) mentions the withdrawal of "privilege" enjoyed by previous rulers to import arms and ammunition from India, which remained a major source for Afghanistan's government. In fact, it has been observed that import of acquisition of advanced arms and ammunition by frontier tribes and Afghanistan had been instrumental in tenacious resistance faced by the British ${ }^{14}$. However, as supply of arms through British India took a hit, Afghanistan started relying on import of arms and ammunition through the Persian Gulf.

The Treaty (Article III) completely abolished the system of subsidy for the rulers of Afghanistan that British would regularly pay to them, in exchange to "follow

\footnotetext{
${ }^{11}$ Leon B. Poullada, Reform and Rebellion in Afghanistan, 1919-1929 - King Amanullah's Failure to Modernize a Tribal Society (Cornell University Press, Ithaca and London, 1973) - pp. 241

${ }^{12}$ See Fraser-Tyler, Afghanistan - A Study of Political Development in Central and Southern Asia (1953) - pp. 197

${ }^{13}$ See Jonathan Lee, Afghanistan - A History from 1260 to the Present (2018) - pp. 460

${ }^{14}$ See Dr. Tim Moreman, Arms Trade on the North West Frontier 1890-1914
} 
unreservedly the advice of the British Government in regard to his external relations".

Most importantly, the "Afghan Government" accepted the "Indo-Afghan Frontier" as already set out in previous agreements. They further undertook to demarcate the undemarcated portion of the frontier "west of the Khyber", where recent incursions had taken place by Afghanistan during the war.

\section{Treaty's Legacy}

The year 1919 could be considered as a watershed moment in Afghanistan's history when they attained "independence" from Britain, predominant power of the time. Afghanistan secured its freedom in conduct of foreign relations including sending and receiving ambassadors and establishing diplomatic relations with other countries. Previous wars were result of direct British intervention and hostilities started by the British. However, the Third Afghan War was started due to Afghan invasion of the British Indian territory. Through the Treaty of Rawalpindi, British at last relinquished control of Afghanistan, reversing their policy of half a century.

The signing of the Treaty was thus considered an event of great celebration in Afghanistan, culminating in Amanullah Khan's letter to British King expressing his thankfulness for British recognition of the Afghanistan's independence. On 19 August 1919, Amanullah Khan declared "independence" from British influence, though the country had never been formally part of the British Empire. To celebrate "victory against British Empire in 1919 and the founding of the nation", Afghans since then have chosen 19 August every year to commemorate Afghanistan's Independence Day. For Afghans, the Third AngloAfghan War was thus considered a "War of Independence".

From the perspective of Afghanistan, Amanullah Khan had started a war with British, ended it, forced the British to come to the negotiating table and secured "independence" for his country. Russia, archenemy of the British, became the first country to recognize Afghanistan as an independent state. However, the US declined to do $\mathrm{So}^{15}$. Whilst the Treaty had unequivocally proclaimed "independence" of Afghanistan from British interference, Lord Curzon, British Foreign Secretary refused to deal with "independent" Afghan Government through any other channel than the British India Office. ${ }^{16}$

It is important to note that the Afghan delegation insisted on using the term "Afghan Government" rather than "Amir of Afghanistan" - a reference to ensure that the Treaty is concluded between two governments rather than with the personality of Amir as British had insisted in case of some agreements

\footnotetext{
${ }^{15}$ See Rosanne Klass, Afghanistan - The Great Game Revisited (1987) - pp. 377

${ }^{16}$ See Amin Saikal, Modern Afghanistan - A History of Struggle and Survival (2004) - pp. 62
} 
concluded between British government and Amir Abdul Rahman. The Treaty also accorded the title of King to Amanullah.

The Third Anglo-Afghan War was primarily over Afghanistan's "independence" from British influence and not on the question of territory. The Treaty affirmed, in no unequivocal terms, prior agreements concerning boundary and demarcation of border between British India and Afghanistan. Even if previous agreements, including the Durand Line Agreement, are considered as "personal undertakings" of earlier Afghan rulers (Amirs), both States agreed to a permanent border through the Treaty of Rawalpindi ${ }^{17}$.

As indicated in Article 4 of the Treaty, a sequel agreement was concluded with the Treaty ${ }^{18}$ between the British and the Afghan Government signed at Kabul on 22 November 1921 with ratifications exchanged at Kabul on 6 February 192219. This Treaty reconfirmed "the Indo-Afghan Frontier as accepted by the Afghan Government under Article 5 of the treaty concluded at Rawalpindi on the $8^{\text {th }}$ of August 1919"20. Article 3 of the 1921 Treaty also allowed receiving of Afghan envoys to London and opening Afghan legations in India, thereby establishing regular diplomatic relations between Afghanistan and the British India.

\footnotetext{
${ }^{17}$ See Ahmed Shayeq Qassem and H.M. Durand, Pak-Afghan Relations: The Durand Line Issue (Policy Perspectives, April 2008 Vol. 5, No. 2, Special Issue: Afghanistan, p. 87-102)

18 "Agreement for establishment of friendly commercial relations between Afghanistan and Great Britain"

${ }^{19}$ Treaty Series No. 19 (1922) published by HM Stationery Office in London, 1922

${ }^{20}$ See Article 2 of the 1921 Treaty. This was in turn again validated by the government of Nadir Shah that came after Amanullah Khan, with the exchange of diplomatic instrument with the British government on 6 July 1930.
} 


\section{Treaty of Peace between the Illustrious British Government and the Independent Afghan Government, concluded at Rawalpindi on August 8, 1919 (11 $1^{\text {th }}$ Ziqada 1337 Hijra), Signed by A. H. Grant, Foreign Secretary, and Ali Ahmad Khan, Commissary for Home Affairs.}

The following Articles for the restoration of peace have been agreed upon by the British Government and the Afghan Government:

\section{Article I}

From the date of the signing of this Treaty there shall be peace between the British Government, on the one part, and the Government of Afghanistan on the other.

\section{Article II}

In view of the circumstances which have brought about the present war between the British Government and the Government of Afghanistan, the British Government, to mark their displeasure, withdraw the privilege enjoyed by former Amirs of importing arms, ammunition or warlike munitions through India to Afghanistan.

\section{Article III}

The arrears of the late Amir's subsidy are furthermore confiscated, and no subsidy is granted to the present Amir.

\section{Article IV}

At the same time, the British Government are desirous of the reestablishment of the old friendship that has so long existed between Afghanistan and Great Britain, provided they have guarantees that the Afghan Government are, on their part, sincerely anxious to regain the friendship of the British Government. The British Government are prepared, therefore, provided the Afghan Government prove this by their acts and conduct, to receive another Afghan mission after six months for the discussion and settlement of matters of common interest to the two Governments and the re-establishment of the old friendship on a satisfactory basis.

\section{Article $V$}

The Afghan Government accept the Indo-Afghan frontier accepted by the late Amir. They further agree to the early demarcation by a British Commission of the undemarcated portion of the line west of the Khyber, where the recent Afghan aggression took place, and to accept such boundary as the British Commission may lay down. The British troops on this side will remain in their present positions until such demarcation has been effected. 


\section{Letter Annexed to Treaty}

Rawalpindi

August 8, 1919

From the Chief British Representative, Indo-Afghan Peace Conference, to the Chief Afghan Representative.

After compliments,

You asked me for some further assurance that the Peace Treaty which the British Government now offer, contains nothing that interfered with the complete liberty of Afghanistan in internal or external matters.

My friend,

If you will read the Treaty carefully you will see that there is no such interference with the liberty of Afghanistan. You have told me that the Afghan Government are unwilling to renew the arrangement whereby the late Amir agreed to follow unreservedly the advice of the British Government in regard to his external relations.

I have not, therefore, pressed this matter: and no mention of it is made in the Treaty. Therefore, the said Treaty and this letter leave Afghanistan officially free and independent in its internal and external affairs.

Moreover, this war has cancelled all previous Treaties. 